\title{
Visual Functions and Aging
}

\author{
João Paulo Cunha* \\ Department of Ophthalmology, Central Lisbon Hospital Center, Portugal
}

Submission: February 23, 2017; Published: March 02, 2017

*Corresponding author: João Paulo Cunha, Department of Ophthalmology, Central Lisbon Hospital Center, Nova Medical School, Universidade Nova de Lisboa, Lisbon, Portugal, Email: cunha.oft@gmail.com

\section{Opinion}

Although visual functions impairment are long been wellrecognized as an important factor in aging process, their contribution to the problems of older persons on tasks in the natural environment are not well known. The literature has shown age-related deterioration of several visual function including visual acuity, contrast sensitivity, dark adaptation, spatial vision and visual processing speed, orientation and motion perception, stereopsis and rivalry, and functional visual field.

All this age-related visual impairment that occurs during normal (non-pathological) aging can be the result of optical, retinal, and central visual pathways/cortical factors/changes. Although optical factors can contribute to age-related declines, more recent research suggests that the declines are primarily the result of cortical changes (sensory and perceptual processing) and retinal/neuronal changes. There are studies showing an age-related degeneration in intracortical inhibition in V1 and in temporal processing speed in areas 17 and 18 [1]. Others studies have shown the trans-synaptic retrograde degeneration of retinal ganglion cells following retrogeniculate visual pathway lesions [2]. Neurophysiological studies suggest that processing declines may be due in part to changes in the level of neurotransmitters associated with cortical inhibition [3].

Recent findings indicate that visual impairment in the elderly has significant influence on health and functional status, with prognostic value as an independent predictor of mortality [4]. Others studies have found evidence that visual impairment increases the risk of falls and fractures, institutionalization and disability to perform basic activities of daily living. Similarly, elderly individuals with decreased visual acuity are 5 times more likely to show impaired cognitive and affective performance [5].
Research programs on how functional/structural eye changes during the course of adulthood can provide information about risk factors or biomarkers for the development of diseases or common conditions. For example, is important to know the biological (e.g., neural, optical) and environmental (e.g., smoking, dietary) factors that can influence the normal versus the pathological aging (e.g., normal visual field for the age).

This deterioration of visual functions related to age makes important to recognize whether this decline can be recovered or prevented. One promising approach in ameliorating agerelated declines in visual function is perceptual learning used to improved visual task performance with practice. The results of our researches on Alzheimer Disease versus Normal-Aging will eventually be useful to develop and evaluate interventions to slow or reverse aging-related declines in vision, thereby improving quality of life.

\section{References}

1. Mendelson JR, EF Wells (2002) Age-related changes in the visual cortex. Vision Res 42(6): 695-703.

2. Jindahra, Panitha, Aviva Petrie, Gordon T Plant (2009) Retrograde trans-synaptic retinal ganglion cell loss identified by optical coherence tomography. Brain 132(pt 3): 628-634.

3. Andersen George J (2012) Aging and vision: changes in function and performance from optics to perception. Wiley Interdiscip Rev Cogn Sci 3(3): 403-410.

4. Jacobs Jeremy M, Hammerman-Rozenberg R, Maaravi Y, Cohen A Stessman J (2005) The impact of visual impairment on health, function and mortality. Aging clinical and experimental research 17(4): 281286.

5. Spierer Oriel, Fischer N, Barak A, Belkin M (2016) Correlation between Vision and Cognitive Function in the Elderly: A Cross-Sectional Study. Medicine (Baltimore) 95(3): e2423. 
(C) This work is licensed under Creative

(C) DOI: $10.19080 /$ JOJ0.2017.02.555579

Your next submission with Juniper Publishers
will reach you the below assets
- Quality Editorial service
- Swift Peer Review
- Reprints availability
- E-prints Service
- Manuscript Podcast for convenient understanding
- Global attainment for your research
- Manuscript accessibility in different formats
( Pdf, E-pub, Full Text, Audio)
- Unceasing customer service
Track the below URL for one-step submission
https://juniperpublishers.com/online-submission.php

